\title{
植物油中のトコフェロール同族体に対する 高速液体クロマトグラフィーの虑用
}

\author{
阿 部 皓 一, 勝井 五 一 郎 \\ エーザイ株式会社研究所
}

\author{
Application of High Speed Liquid Chromatography for \\ Determination of Tocopherols in Vegetable Oils \\ Kouichi ABE, Goichiro KATSUI \\ Eisai Research Laboratories, Bunkyo-ku, Tokyo
}

\begin{abstract}
A high speed liquid chromatographic (HSLC) with a spectrofluorometer method was applied for the determination of $\alpha-, \beta-, \gamma-, \delta$-tocopherols in vegetable oils.

It was found that tocopherols in vegetable oils were almost present in free forms. Vegetable oils in solvent, therefore, were possible to inject directly on to the column without any pretreatment.

Experimental procedure was as follows: Samples of oils dissolved in $n$-hexane were injected directly onto the column, which was a normal phase partition column, JASCOPACK WC-03. Separation of tocopherols was carried out by employing a mixture of diisopropylether and $n$-hexane $(2: 98, \mathrm{v} / \mathrm{v})$ as the mobile phase. The eluant was monitored continuously by a spectrofluorometer. The recovery of tocopherols added into soybean oil was approximately $103,98,102$, and $96 \%$ for $\alpha-, \beta-, \gamma-$, and $\delta$-tocopherols, respectively.

The HSLC method have found to offer more rapid, simple, and accurate technique than conventional methods for determining $\alpha-, \beta-, \gamma-$, and $\delta$-tocopherols in vegetable oils.
\end{abstract}

(Received June 11, 1975)

トコフェロール（Toc）が栄養素として重要なことは 古くから知られているところであるが，近年高度不飽和 脂肪酸摄取との関連性に批いて久くことのできない栄養 素であることが明確となり，フメリカ合采国等ではその 所要量が示されるに至っている1”。

わが国のよらに魚類扣よび植物油摄取の多い国では PUFA 摄取の機会が多く, したがって Toc の必要性も 高いと考えられるが，その調査が十分にされておらず， 日常摄取している食品中の Toc 含量さ光十分注調べら れていない。そこで，食品中の Toc を比較的簡易に定 量する方法の確立を考え研究をすすめてきたが，Toc に はいくつかの同族体があり、それぞれの生理効果が異な っているので, 定量法も分離定量法でなければならな い。

分離定量法としては薄層クロマトグラフィー2) (TLC), ガスクロマトグラフィー3) (GLC), ダルクロマトグラフ 1ーの等があり，われわれも TLC や GLC について検

†食品中のトコフェロール同族体の高速液体クロマト クラフィーによる定量（第1 報）

Determination of Tocopherols in Food by High Speed Liquid Chromatography (Part 1)

₹ 112 東京都文京区小石川 4-6-10
討し，その一部はすでに発表した5)。しかしながら、こ れらの方法は操作が煩雑であったり， $\beta$-Toc と $\gamma$-Toc との分別ができなかったりして，な満足できるもので はなかった。ところが，われわれがさきに報告した高速 液体クロマトグラフィー (HSLC) の方法6)をこれに応 用したところ，微量の試料を用いて短時間に精度よく同 族体を分離定量することができた。

ただし，われわれの HSLC 条件では，油脂を有機溶 媒に溶かし, 直接カラムに注入して定量するので, 大豆 等の殼類の場合は，まず油脂を抽出しなければならな い。固形試料からの油脂抽出は，その条件によって抽出 率が異なるので，抽出条件を明確にしておかないと真の Toc 量を算出することができない。この点については別 に検討し，その条件を定めたらえで，殼類等の固形食品 の Toc 量を測定して報告することとし, 今回は油脂中 の Toc 同族体を定量した成績を報告する。

\section{実 験 方 法}

\section{1. 試料}

線実油，大至油，小麦胚芽油，いずれも方眅品を用い た。

アーモンド, ピーカンナッッ, ブラジルナッッ, へー 
ゼルナッツ, 松の実, ピスタチオナッッ, ピーナッツの 油脂のらち前の六つは市販の生のもの, ピーナッッは口 一スト味付した市販品をそれぞれ乳鉢で注意してすりつ ぶしたのち,ソックスレー抽出器を用い, エーテル抽出 して得た油脂を用いた。

\section{2. 試 菜}

純 $\alpha, \beta, \gamma, \delta$-Toc 既報 ${ }^{5}$ の方法に準じて処理し, $\alpha, \beta, \gamma, \delta$-Toc の純品を得た。これらは標準品として HSLCにおける保時時間やピーク高を調へ，検量線を作 製するのに用いる。酸化を受けやすいので, かっ色ガ スびんに入れ, 空気を $\mathrm{N}_{2}$ ガスで固換し, 密せんして冷 暗所に保存する。

イソプロピルエーテルは市販特級のものを, $n$-ヘキサ ンは吸収スペクトル分析用のるのを実験に用いた。

3. 装置

高速液体クロマトグラフ 分光螢光光度計 (JASCO FP-4) 付 JASCO FLC-350

分析条件は次のとおりである6゙。

カラム : JASCOPACK WC-03-500 (2.3 i.d. $\times 500$ $\mathrm{mm}$ )

移動相 : イソプロピルェーテル・n-ヘキサン $(2: 98, \mathrm{v} / \mathrm{v})$

流速 : $0.8 \mathrm{ml} / \mathrm{min}$

検出器 : JASCO FP-4

(Ex $298 \mathrm{~nm}, \operatorname{Em} 325 \mathrm{~nm})$

この条件での $\alpha, \beta, \gamma, \delta$-Toc の $t_{R}$ はそれぞれ 4.4, $9.6,12.6,18.0 \mathrm{~min}$ である。

\section{実 験 成 績}

\section{1. 食品中の Toc 同族体の形㸃}

食品中の Toc 同族体がェステル型で存在するか, 遊 離型で存在するかによって定量操作法を変えなければな らないので,この点を調べた。

すなわち大豆油, 綿実油, 小麦胚芽油等の油脂を直接 n-ヘキサンに溶かし，HSLC カラムに注入して䖝光法で 定量する方法を直接法とし, 試料を抗酸化剂の存在下に アルカリけん化》) して得た不けん化物を，n-へキサンに 溶かして HSLC カラムに注入して䖝光法で定量する方
法をけん化法とした。そして, 雨者の各 Toc の分析値 を比較した。Table 1 に示すように，值接法とけん化法 で得られた分析値は一致した。したがって, 試検した油 脂中の Toc は遊離型として存在しており, エステル型 として存在しても微量である。それゆえに，一般の油脂 の Toc 類の定量は, 直接法を採用して差し支えないこ とがわかった。

\section{2. 定量阻害物の検討}

食品中の油脂類には Toc 同族体のほか, ビタミンA，

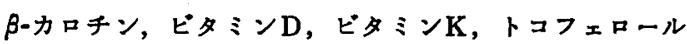
キノン,コレステロールあるいは植物ステロール類等の 脂溶性物質が存在するので，これらの物質による定量へ の阻害を検討した。Toc 䖝光定量の条件 (Ex $298 \mathrm{~nm}$, $\operatorname{Em~} 325 \mathrm{~nm})$ で, これらの物質の定量阻害の程度を調べ たところ，ほとんと阻害しないことがわかっだ。ただ し, $\gamma$-Toc $0.2 \mu \mathrm{g}$ に対しビタミンA 3.2 IU 以上にな ると，䖝光の再吸収がおこって $\gamma$-Toc の定量值が低く なるので，ビタミンAを大量に含有する食品ではビタ ミ ンAの除去操作が必要となる。また，ゴマ油の中には， $\delta$-Toc のピークに Toc 以外の䖝光物質が重なり定量を 阻害するので，この物質の除去操作が必要である。しか し,これらは特殊な例であり，一般の植物油ではこのよ らな定量阻害がみられないので, 直接法で Toc 同族体 の定量ができる。

3. 回收乘

大豆油に既知量の $\alpha, \beta, \gamma, \delta$-Toc を加えて回収率を求 めた。その結果は, Table 2 に示したように, $100 \%$ 近 い回収率であった。それゆえに，本法による定量值の信 頼性は高いといえる。

\section{4. 实験操作法}

以上の実験結果から，定量法として直接法を採用する こととした。すなわち, 試料 $A \mathrm{~g}$ を $n$-ヘキサンに答か し正確に $B \mathrm{ml}$ とする。各 Toc 同族体含量を $0.1 \sim 3.0$ $\mathrm{mg} / \mathrm{ml}$ 程度とする。その $C \mu l(1 \sim 10 \mu l)$ をマイクロ シリンジを用いて HSLC カラムに注入して分析をおこ ない,それぞれのピーク高を測定する。別にさきの純 $\alpha, \beta, \gamma, \delta$-Toc を用いて検量線をつくっておき, これに 対比して $C \mu l$ 中の Toc 同族体の量 $D_{(\alpha \sim \delta)} \mu \mathrm{g}$ を算出

Table 1. Comparison of the result of direct method with saponification method.

\begin{tabular}{|c|c|c|c|c|c|c|c|c|c|c|}
\hline & \multicolumn{5}{|c|}{ Direct method } & \multicolumn{4}{|c|}{ Saponification method } & \multirow[b]{2}{*}{ Total } \\
\hline & $\alpha$-Toc & $\beta$-Toc & $\gamma$-Toc & $\delta$-Toc & Total & $\alpha$-Toc & $\beta$-Toc & $r$-Toc & $\delta$-Toc & \\
\hline Soybean oil & 6 & - & 42 & 14 & 62 & 6 & - & 42 & 15 & $63^{\circ}$ \\
\hline Cotton seed oil & 31 & - & 33 & - & 64 & 31 & - & 33 & - & 64 \\
\hline Wheat germ oil & 180 & 74 & 10 & - & 264 & 177 & 70 & 12 & - & 259 \\
\hline
\end{tabular}


Table 2. Recovery of tocopherols.

\begin{tabular}{lccccc}
\hline & $\begin{array}{c}\text { Soybean oil } \\
(A) \mu \mathrm{g}\end{array}$ & $\begin{array}{c}\text { Added } \\
\text { tocopherol } \\
(B) \mu \mathrm{g}\end{array}$ & $\begin{array}{c}\text { Total } \\
\text { tocopherol } \\
(A+B) \mu \mathrm{g}\end{array}$ & $\begin{array}{c}\text { Observed } \\
\text { tocopherol } \\
(C) \mu \mathrm{g}\end{array}$ & $\begin{array}{c}\text { Recovery } \\
\left(\frac{C}{B}-A^{-} \times 100\right)\end{array}$ \\
\hline$\alpha$-Toc & 19 & 88 & 107 & 110 & $103 \%$ \\
$\beta$-Toc & - & 50 & 50 & 49 & $98 \%$ \\
$\gamma$-Toc & 84 & 57 & 141 & 142 & $102 \%$ \\
$\delta$-Toc & 30 & 52 & 82 & 80 & $96 \%$ \\
\hline
\end{tabular}

Table 3. Tocopherol composition of vegetable oils.

\begin{tabular}{lrrrrr}
\hline \multicolumn{1}{c}{ Oils } & $\alpha$-Toc & $\beta$-Toc & \multicolumn{1}{c}{ r-Toc } & d-Toc & Total \\
\hline Cotton seed & 309 & - & 330 & - & 639 \\
Soy bean & 59 & - & 418 & 140 & 617 \\
Wheat germ & 1796 & 735 & 99 & - & 2630 \\
Almond nut & 461 & - & - & - & 461 \\
Pecan nut & 4 & - & 178 & - & 182 \\
Brazil nut & 46 & - & 185 & - & 231 \\
Hazel nut & 346 & - & - & - & 346 \\
Pine nut & 221 & - & 104 & - & 325 \\
Pistachio nut & 16 & - & 439 & 24 & 479 \\
Peanut & 37 & - & 37 & 20 & 94 \\
\hline \hline
\end{tabular}

する。たとえば綿実油なら $1 \mathrm{~g}$ を nーヘキサンにとかし， 正確に $5 \mathrm{ml}$ としてその $5 \mu l$ を注入して分析した。

試料油脂中の Toc 同族体の量は, 次の計算式によっ て算出する。

油脂中の Toc 同族体の量 $(\mu \mathrm{g} / \mathrm{g})$

$$
=D_{(a \sim \delta)} / A \times B / C \times 1000
$$

\section{5. 油脂類の Toc 同族体の含量}

綿実油等, 油脂類の試料を前述の実験操作法に従って 定量した成績を示すと，表了のと括りとなった。これ

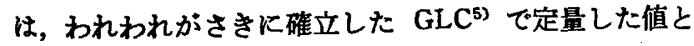
はぼ一教した。

$$
\text { 考察 }
$$

従来, 油脂中の Toc 同族体の定量法として, TLC, GLC 等があるが，操作が煩雅であったり， $\beta$ と $\gamma$-Toc との分離が困難であったりする欠点があり，満足できる あのではなかった。

しかしわれわれが確立した HSLC 条件では，徽量の 試料を用いて迅速に，精度よくToc 同族体を定量しえ た。ただしビタミンAを大量に含む試料については䖝 光の再吸収がおこって $r$-Toc の值が低くなるので, ビ
タミンA除去の前操作が必要である。またコマ油では $\delta$-Toc のピーク部分に Toc 以外の䖝光物質が重なり, 誤った判定を下すことになるので，盲䖝光物質の除去が 必要である。なお，植物油にはトコトリェノールも存在 するので, 今後, 検討する。

このように，今後な和検討して解決せねばならない問 題もあるが，一般の食品の油脂は本法によってたやすく 定量することができる。

$$
\text { 要旨 }
$$

1. 従来定量が容易でないといわれていた食用油脂中 の Toc 同族体の定量に HSLC を応用して, 微量の試料 で簡便，正確に定量することができた。

2. 植物油中の Toc 同族体は遊離型であることを確 認したので, $n$ ーヘキサンにとかして直接カラムに注入し て定量した。各 Toc の回收率は、ほぼ 100\% であっ た。

3.上記の方法で, 綿実油など 10 種類の油脂中の Toc 同族体を定量した。

本稿を終えるにあたり，試料の一部を提供してくださ った，扣茶の水女子大学福場博保教授に深謝いたしま す。

\section{文献}

1) Bieri, J.G.: J. Amer. Diet. Ass., 64, 171 (1974)

2) Chow, C.K. and Draper, H.H. : Anal. Biochem., 32, 81 (1969)

3）石川端二, 勝井五一郎 : ビタ ミン, 34, 185 (1966)

4) Thompson, J.N. and Erdody, P. and Maxwell, W.B. : Anal. Biochem., 50, 267 (1972)

5) 阿部皓一, 涌口泰昌, 勝井五一郎 : 栄羕と食糧, 27, 329 (1974)

6) Abe, K., Yuguchi, Y. and Katsui, G. : J. Nutr. Sci. Vitaminol., 21, 183 (1975)

7) 勝井五一郎：ビタ ミン, 38, 151 (1968)

8) 阿部艁一, 勝井五一郎 : ビタミン, 49, 259(1975) (昭和50年 6 月11日受理) 